\title{
タイルの大きさ，形状などを要因としたずれ感覚を表示する 物理量の設定
}

視覚的観点からみたタイル壁面の仕上げ精度の評価方法に関する研究（その 2)

ESTABLISHMENT OF QUANTITATIVE VALUE CORRESPONDING TO HUMAN SENSE ON ACCURACY ON THE SUBJECTS OF VARIOUS SIZES AND FORMS OF TILES

Study on the method for evaluating accuracy of finishing of tiled walls from a viewpoint of sense of sight (Part 2)

横山 裕*, 松原道彦**

Yutaka YOKOYAMA and Michihiko MATSUBARA

\begin{abstract}
This paper presents the quantitative value corresponding to human sense on accuracy on the subjects of various sizes and forms of tiles. Firstly, the sensory scale relating to accuracy of finishing of the tiled walls employing the sensory test was constructed. On the other hand, the geometric measurement on accuracy of finishing of the tiled walls was carried out. Secondly, the quantitative value was established from the relationship between the result of the measurement and the sensory scale. The quantitative value is what developed from another quantitative value established in the former report on the subject of one tiled wall.
\end{abstract}

keywords: tiled wall, accuracy of finishing, sense of sight, size and form of tile. human sense on accuracy, quantitative value タイル壁面, 仕上げ精度, 視覚, タイルの大きさおょび形状, ずれ感覚, 物理量

\section{1. 序論}

本研究は、タイルのずれが目立つ、凹凸が大きく見苦 しいなど、仕上げ精度の悪さが視覚的観点から問題とな るタイル壁面の增加を防ぐために必要と考えられる、視 覚的観点からみたタイル壁面の仕上げ精度の評価方法を 提示することを、最終的な目的としている。

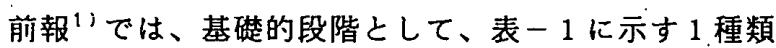
のタイル壁面を対象に種々の基礎的検討を行った経過, 結果を報告した。具体的には、ずれの目立ちやすさの観 点から代表的な観察位置を設定するとともに、壁面の中 の 1 枚のタイルのずれに関する判断が壁面内のどの程度 の範囲から得られる視覚情報によりなされているかを表. す判断対象範囲を究明し、さらに壁面の仕上げ精度と夕 イルのずれの感覚上の大きさ（どの程度ずれているよう に見えるかを表すすので、以降 “ずれ感覚”之記す）と の関係を検討し、ずれ感覚を表示する物理量を設定した 経過, 結果を述べた。本報は、前報で対象とした壁面と タイルの大きさ，形状などが異なる壁面にも適用できる、
ずれ感覚を表示する物理量を設定した経過，結果を述べ るむのである。

なお、本研究の背景，意義および関連する既往の研究 などは前報で述べている。また、本報の一部の概要は日 本建築学会大会に報告している3゙。

\section{2. 本研究の目的, 䡉囲}

本研究では、1 種類のタイル壁面を対象とした前報の 結果を参考に、新たにタイルの大きさ，形状などを要因 として取り入れることにより、前報で対象とした壁面と タイルの大きさ，形状などが異なる壁面にも適用できる

\section{表一 1 前報で対象としたタイル壁面の概要}

\begin{tabular}{|c|c|}
\hline タイル各辺の長さ & 轱 $45 \times$ 横 $95 \mathrm{~mm}$ \\
\hline 目地幅 & $5 \mathrm{~mm}$ \\
\hline タイルの色 & 白 \\
\hline 目地の色 & 存色 \\
\hline 目地の入り方 & 芋目地 \\
\hline
\end{tabular}

*名古屋工業大学工学部社会開発工学科 助教授・工博

** 名古屋工業大学 大学院生
Assoc. Prof., Dept. of Architecture and Civil Eng., Faculty of Eng., Nagoya Institute of Technology, Dr. Eng. Graduate Student, Nagoya Institute of Technology 
ずれ感覚を表示する物理量を設定することを目的とする。 本研究で設定する物理量は、仕上げ精度の評価方法の 提示に必要な、種々のタイル壁面に適用できるずれの目 立ちやすさを表示する物理量設定のための基礎資料とな るすのである。すなわち本研究で設定する物理量に、ず れの目立ちゃすさに影響すると思われるタイル，目地の 色や目地の人り方などの要因を加味することにより、夕 イル，目地の色や目地の入り方などのいかんにかかわら ず適用できるずれの目立ちやすさを表示する物理量が設 定できるすのと思われる。なお、ずれの目立ちやすさを 表示する物理量については、次報以降で報告する予定で ある。

本研究で対象とするずれ感覚は、前報で述べたと同様 の理由から、タイル壁面全体に対するずれ感覚（壁面全 体としてどの程度ずれているように見えるか）ではなく、 壁面の中の指定した 1 枚のタイル (以降“判断対象タイ ル”と記す）に対するずれ感覚とする。

また照度，光源位置などの照明条件す、前報と同様、 外壁として一般的な条件とする。すなわち照度は屋外昼 間における一般的な範囲である $5.000 \sim 20.0001 \times$ とし、各 タイル表面の輝度に有意な差はなく、かつ光源からの反 射光が直接観察位置に達しない条件とする。なお夕イル 表面の輝度の差により認識されるずれに関する検討は、 今後の課題とする。

さらに本研究では、仕上げ精度の許容範囲の提案、ず れや凹凸などが目立ちにくい夕イル壁面の開発および高 い仕上げ精度が確保できる新たな工法の開発などは、範 囲外とする。

\section{3. 本研究の手順および研究方法}

タイルに対するずれ感覚は観察位置により変化するこ とが容易に予想されるが、視覚的観点からみた仕上げ精 度の評価方法提示を目的とした本研究では、はじめにず れの目立ちやすさの観点から代表的ないくつかの観察位 置を設定し、設定した位置から観察した場合のずれ感覚 を対象に研究を進めるのが妥当といえる゙。

一方、表一1に示したタイル壁面を対象とした前報で は、ずれが最す目立つ観察位置に関する官能検查結果よ り、ずれの目立ちやすさの観点から代表的な観察位置 （観察角度および観察距離）を図ー1に示すごとく設定 している。このうち観察角度は、我々が日常種々のタイ ル壁面を観察する際に経験的に得ている知見と大きく異 なるむのではなく、タイルの大きさ，形状などにより大 きく変化するとは考えにくいことから”、本研究ではは じめに観察距離について再検討し、つぎにず机感覚を表 示する物理量について検討することとした。

以下に本研究の手順および研究方法を示す。

1) いくつかの実在建築物のタイル壁面からタイルの大

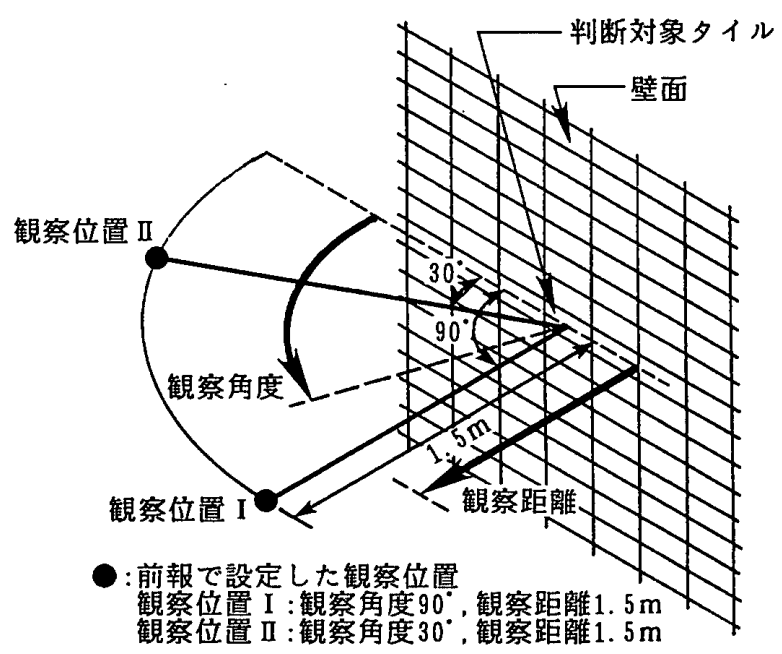

図ー1 前報で設定した観察位置

きさ，形状などが異なる種々の壁面を選定するとと もに、壁面を観察する際の距離を自由に移動できる ようにし、官能検查手法を適用して判断対象タイル のずれの目立ちやすさと観察距離の関係を考察する。

2 ) 実在するタイルの大きさ，形状などの範囲を参考に、 タイル壁面の種類と判断対象タイルのずれの程度の 組合せからなる数十体の試料壁面を製作する。

3）２）で製作した試料壁面を用い、官能検查手法およ び尺度構成理論を適用してずれ感覚に関する心理学 的尺度を構成する。その際の観察距離は、1）の結 果より設定する。

4）２）で製作した試料壁面の仕上げ精度を測定する。

5 ） 3) で構成した心理学的尺度と 4 ) で測定した仕上 げ精度との関係を種々検討し、ずれ感覚を表示する 物理哩を設定する。

\section{4.锶察距䧺とずれの目立ちゃすさの関係の考察}

4.1 本節の目的

本節の目的は、種々のタイル壁面を対象に壁面を観察 する際の距離とずれの目立ちやすさとの関係を考察し、 ずれ感覚に関する官能検查の際の観察距離を設定するた めの基礎資料を得ることにある。

\section{2 ずれが最む目立つ観察距離に関する官能検查}

\section{2.1 官能検查概要}

\subsubsection{1 検查方法}

本検査では、観察距離を自由に変化させられる条件で 検查員に判断対象タイルのずれが最す目立つ距離を对ね、 回答を求めることとした。観察角度は前報で設定したず

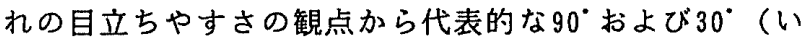
ずれあ図ー1参照)とし、それぞれの角度ごとに判断対 象タイルのずれが最も目立つ観察距離を求めることとし た。 


\subsubsection{2 検查試料}

いくつかの実在建築物のタイル壁面から検查試料とし てタイルの大きさ，形状などが異なる11種類の壁面No. 1 〜11を選定し、各壁面からずれが最も目立つと思われる タイルを判断対象タイルとして選定した。選定した壁面 の概要を表一. 2 に示す。壁面№. 1 〜 11 選定にあたって は、実在するタイルの大きさ，形状などの範囲をできる だけ包含する試料群とすること、2．で述べた照明条件 が満足された壁面であること、検查の際に十分な観察距 離が確保できる壁面であること、検查員の移動をともな う検査であるので試料数をできるだけ少なくすることな どに留意した。

なおタイル，目地の色は観察距離に関する判断に大き く影響しないと想定されたことから、本検査では種々の 色の壁面を検查試料として選定し、検査結果に基づいて タイル，目地の色によりずれが最す目立つ観察距離が大 きく変化しないことを確認することとした。また目地の 入り方も観察距離に関する判断に大きく影響しないと想 定されたが、試料数の制約から、本検査では比較的使用 頻度が高くかつずれが目立ちやすいと思われる芋目地に 統一することとした。

\subsubsection{3 検查員}

検查員として、健常な成人男子 6 名（年齢21～31嵅, 視力1.0〜1.5）を選定した。

\subsection{2 官能検查経過, 結果}

4.2.1で述べた条件の他に、あくまであ判断対象タイル 1 枚のずれにのみ着目すること、疲れたらいつであ自由 に休めることなどを条件に加え、官能検查を実施した。 検查員 1 名が 1 つの壁面に対する判断に要した時間は、 おおむね 1 分であった。

官能検查結果を図ー2 に示す。図は各壁面ことに各検 查員がずれが最す目立つと回答した観察距離を示したす のであり、図中の記号は観察角度により分類したもので ある。なお横軸は、タイル1枚の面積が小さい順に壁面 №. 1 〜11を示したすのである。
4.3 観察距離よずれの目立ちやすさの関係の考察 図-2 から以下の事項が考察できる。

・比較的大きなタイルからなる壁面№.11では、回答のあ った観察距離の下限が他よりやや大きくなる傾向がう かがえる。これは検查員が壁面観察時に他の壁面より 大きな範囲を視界に入れる必要があったためと思われ る。

・壁面No.11以外では、ずれが最す目立つ観察距離はおお むね $1 \sim 5 \mathrm{~m}$ に分布しており、分布の中心はいずれの 壁面です $1 \sim 3 \mathrm{~m}$ である。このことから、ずれが最す 目立つ観察距離の範囲は $1 \sim 3 \mathrm{~m}$ でありタイルの大き さ，形状などによりほとんど変化しないこと、1〜 $3 \mathrm{~m}$ 範囲ではずれの目立ちやすさは観察距離により 大きく变化しないことがわかる。なお壁面No.11のずれ が最も目立つ観察距離の範囲は、2〜3 $\mathrm{m}$ とみなせる。 ・ずれが最も目立つ観察距離の範囲は、観察角度により 大きく変化しない。

・4.2.1.2で想定した通り、ずれが最す目立つ観察距離の 範囲はタイル，目地の色により大きく变化しないこと が確認できる。

以上を総括すると、タイルのずれを判断するには周囲 のタイルを自然に視界に入れることができるだけの観察 距離を確保する必要があること、この距離が確保されて いる場合、ずれが最も目立つ観察距離の範囲はタイルの 大きさ, 形状などによらず $1 \sim 3 \mathrm{~m}$ でありタイル, 目地 の色および観察角度により大きく変化しないこと、1〜 $3 \mathrm{~m}$ 範囲ではずれの目立ちやすさは観察距離によりほ とんど変化しないことが、明らかになったといえる。な お前報で設定したずれの目立ちやすさの観点から代表的 な観察距離は $1.5 \mathrm{~m}$ であり、本研究で求めたずれが最も目 立つ観察距離の範囲に含まれることを付け加える。

\section{5．ずれ感覚を表示する物理量の設定}

5.1 本節の目的

本節の目的は、壁面の仕上げ精度とずれ感賞との関係
表 -2 壁面№. $1 \sim 11$ の概要

\begin{tabular}{|c|c|c|c|c|c|}
\hline $\begin{array}{l}\text { 壁面 } \\
\text { №. }\end{array}$ & $\begin{array}{c}\text { タイル各辺の長さ } \\
\text { 繸 } \times \text { 横 (mu) }\end{array}$ & $\begin{array}{r}\text { 目地偪 } \\
(\mathrm{mm})\end{array}$ & タイルの色 & 目地の色 & \begin{tabular}{|l|} 
目地の \\
入り方 \\
\end{tabular} \\
\hline 1 & $45 \times 45$ & 5 & 茶色 & 白 & \\
\hline 2 & $45 \times 95$ & 5 & 白 & 黒 & \\
\hline 3 & $60 \times 108$ & 10 & 明るい灰色 & 灰色 & \\
\hline 4 & $45 \times 145$ & 5 & 明るい灰色 & 灰色 & \\
\hline 5 & $60 \times 227$ & 8 & 白 & 黒 & \\
\hline 6 & $95 \times 45$ & 5 & 青 & 白 & 孛目地 \\
\hline 7 & $95 \times 95$ & 5 & 灰色 & 黒 & \\
\hline 8 & $140 \times 140$ & 10 & 白 & 黒 & \\
\hline 9 & $193 \times 93$ & 7 & 白 & 灰色 & \\
\hline 10 & $227 \times 60$ & 8 & クリーム色 & 灰色 & \\
\hline 11 & $300 \times 300$ & 3 & ねずみ色 & 黒 & \\
\hline
\end{tabular}

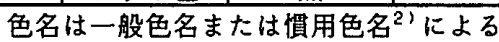

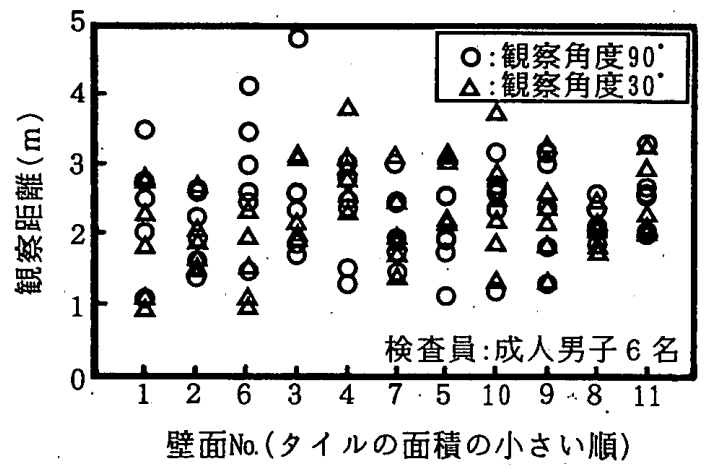

図-2 観察距離に関する官能検查結果 


\section{表一 3 試料壁面の概要}

\begin{tabular}{|c|c|c|c|c|c|c|c|c|}
\hline & $\begin{array}{c}\text { タイル各匄の長さ } \\
\text { 縦 } \times \text { 横 (mm) }\end{array}$ & $\begin{array}{r}\text { 目地幅 } \\
(\mathrm{mm})\end{array}$ & $\begin{array}{c}\text { タイルの } \\
\text { 色 }\end{array}$ & $\begin{array}{c}\text { 目地の } \\
\text { 色 }\end{array}$ & $\begin{array}{l}\text { 目地の } \\
\text { 入り方 }\end{array}$ & $\begin{array}{r}\text { 施工タイル枚数 } \\
\text { 縦 } \times \text { 横(枚) }\end{array}$ & $\begin{array}{l}\text { タイル製 } \\
\text { 試料数(体) }\end{array}$ & $\begin{array}{l}\text { 紙製 } \\
\text { 試料数 (体) }\end{array}$ \\
\hline$\overline{\mathrm{A}}$ & $45 \times 45$ & 5 & \multirow{6}{*}{ 白 } & \multirow{6}{*}{ 黒 } & \multirow{6}{*}{ 芋目地 } & $5 \times 5$ & 1 & 8 \\
\hline B & $45 \times 95$ & 5 & & & & $5 \times 3$ & 1 & 8 \\
\hline $\bar{C}$ & $45 \times 95$ & 10 & & & & $5 \times 3$ & 0 & 8 \\
\hline $\mathrm{D}$ & $60 \times 227$ & 8 & & & & $7 \times 3$ & 1 & 8 \\
\hline$E$ & $227 \times 60$ & 8 & & & & $3 \times 7$ & 1 & 8 \\
\hline $\bar{F}$ & $196 \times 196$ & 6 & & & & $3 \times 3$ & 1 & 8 \\
\hline
\end{tabular}

を考察し、ずれ感覚を表示する物理量を設定することに ある。

5.2 試料壁面の製作

ずれ感覚を表示する物理量設定のための試料壁面とし て、A〜Fの 6 種類のタイル壁面と、壁面中の判断対象 タイルのずれの程度 8 〜段階との組合せからなる53体 の試料壁面を製作した。表一 3 に試料壁面の概要を示す。 タイル壁面 $\mathrm{A} \sim \mathrm{F}$ の選定にあたっては、比較的使用頻度 が高い実在タイルの大きさ，形状などの範囲を包含する 試料群とすること、目地幅がずれ感覚におよぼす影響に ついて検討できる試料群とすることなどに留意した。こ こで壁面Bのタイルの大きさ，形状などは、前報で対象 としたタイル壁面と同一である。一方判断対象タイルの ずれの程度 8 〜 段階の設定にあたっては、タイル壁面 ごとにずれが非常に小さいものから非常に大きいものま でを包含する試料群とすることに留意した。

タイル壁面ごとの試料数は表一 3 に示す通りである。 本研究では、試料壁面製作時の労力軽減の観点から、 表ー3に示す通り、53体の試料壁面のうち 5 体をタイル， 目地材を用いて製作することとし（以降“タイル製”と 記す）、48体は紙製とすることとした。これは、試料壁 面から得られる視覚刺激とずれ感覚との関係が求められ れば、試料壁面がどのような材料で製作されたものであ っても本研究の目的は達成されることによる。なお同等 の視覚刺激が得られるタイル製試料と紙製試料から同等 のずれ感覚が得られるかどうかの確認は、製作した試料 壁面を用いてずれ感覚を表示する物理量が設定された段 階で、タイル製試料と紙製試料の結果を比較することな どにより行うこととした。

また試料壁面のタイル，目地の色および目地の入り方 は、白，黒および芋目地に統一することとした。これは、 判断対象タイルのずれ感覚上の相対的序列は夕イル, 目 地の色および目地の入り方などのずれの目立ちやすさに 影響すると思わ扎る要因が本研究と異なる条件に統一さ れた場合であ大きく変化しないと想定されたこと、ずれ 感覚に関する判断を精度よく求めるためには試料壁面は 比較的ずれが目立ちやすいと思われる条件（タイル，目 地ともに無彩色でかつ色の差が大きく、縦，横目地とも

\section{表ー4 ずれ感覚に関する官能検查概要}

\begin{tabular}{|c|c|}
\hline 構成する尺度 & ずれ感覚尺度 \\
\hline 検查手法 & 系列範亏 う法 \\
\hline 判断範ちゅう & 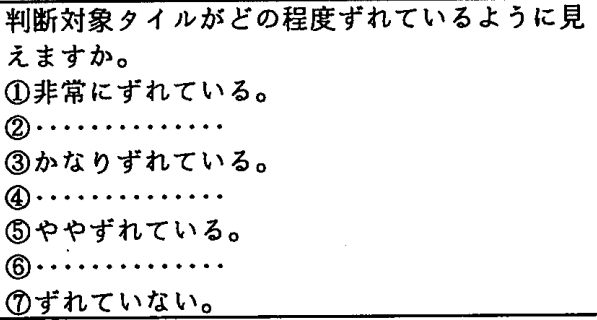 \\
\hline 検查員 & 成人男女 10 名 $(20 \sim 22$ 歲, 視力 $0.8 \sim 1.5)$ \\
\hline 榆查武料 & 表一 3 に示す53体の試料壁面 \\
\hline 観察位置 & 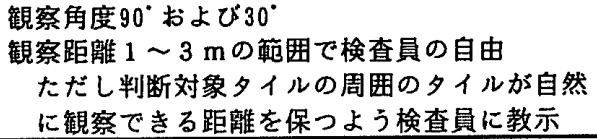 \\
\hline
\end{tabular}

に連続）に統一するのが有利であると想定されたことに よる。

さらに 1 体の試料壁面に施工するタイルの枚数は、前 報で究明した判断対象範囲が判断対象夕イルに周囲 8 枚 を加えた $3 \times 3=9$ 枚のタイルの範囲であることから、 基本的に $3 \times 3=9$ 枚とした。ただし、ずれに関する判 断の際 9 枚の䡉囲外のタイルが自然に視界に入りやすい と思われる比較的小さい夕イルからなる壁面や辺長比の 大きいタイルからなる壁面の短辺方向に関しては、9枚 のタイルの範囲外から得られる視覚情報がず机に関する 判断に大きく影幚しないことを確認する目的で、表ー 3 に示す通り施工するタイルの枚数を適宜追加した。

以上の条件にしたがって、所定のタイル，目地材また は紙を $900 \times 900 \mathrm{~mm}$ 合板に施工し試料壁面とした。 5.3 ずれ感覚に関する官能検查および心理学的尺度の構 成

\section{3 .1 官能検查概要}

官能検查の概要を表ー4に示した。以下におすな事項 について説明を加える。

\subsubsection{1 構成する尺度および尺度構成手法}

構成する尺度は、判断対象夕イルがどの程度ずれてい るように見えるかを表す尺度（以降 “ずれ感覚尺度”と 記す）とし、尺度構成手法は系列範ちゅう法 ${ }^{\natural}$ とした。 
判断範ちゅうは表ー 4 に示す通りである。

\subsection{2 検查試料}

5.2で製作した53体の試料壁面を検査試料とした。

5.3.1.3 観察位置

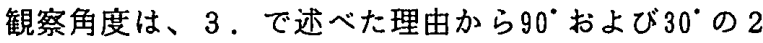
種類とした。

また観察距離は、4.3で求めたずれが最も目立つ観察距 離の範囲内とすることとした。具体的には、判断対象夕 イルの周囲のタイルを自然に視界に入れることができる 距離を確保するよう検査員に教示したうえで、1〜 $3 \mathrm{~m}$ の範囲で検查員の自由とした。

\subsubsection{4 検查員}

検查員として、健常な成人男女10名（年齢20〜22歳， 視力0.8〜1.5）を選定した。

5.3 .2 官能検查経過, 結果および心理学的尺度の構成

5.3:1で述べた条件の他に、ずれの目立ちやすさなどで はなくあくまです判断対象タイルがどの程度ずれている ように見えるかにのみ着目すること、疲れたらいつであ 自由に休めることなどを条件に加え、官能検查を実施し 基礎データを得た。

検查は、外部からの光が遮断された検查室に2．で述 べた条件を満足させられる照明器具を設置し、タイル製 試料と紙製試料でタイル，目地の色などに有意な差がな いことを輝度，色度の測定結果および目視により確認し たうえで行った。なお検查員 1 名が 1 つの検查試料に対 する判断に要した時間は、おおむね 1 分であった。

官能検査の結果得られた基礎データの分散分析結果を 表 -5 に示す。主効果の分散比が高度に有意でありかつ 寄与率も大きいことから、検查試料の刺激に十分な差が あること、本検查自体が有効であることがわかる。また 個人差の分散比む有意となっているが、分散比, 寄与率 ともに主効果の分散比, 寄与率と比較して小さいことか ら、構成される尺度は個人差が内包されるむのの十分有 効とみなすことができる。

以上から、官能検查の結果得られた基礎デー夕を用い、 尺度構成理論 ${ }^{4}$ にしたがってずれ感覚尺度を構成した。

\section{4 仕上げ精度の測定}

5.2で製作した試料壁面の仕上げ精度を測定するための 装置を製作した。装置の概要を図ー 3 に示す。

本装置は、測定対象とする試料壁面に取り付けた固定 フレーム上に上下移動フレームを載せ、さらに上下移動 フレーム上に左右移動フレームを載せたもので、2つの

\section{表 -5 分散分析結果}

\begin{tabular}{|l|c|c|}
\hline & 分散比 & 寄与率 \\
\hline 主效果 & $74.0116 \%$ & $86.51 \%$ \\
\hline 個人差 & 16.1263 落 & $1.54 \%$ \\
\hline \multicolumn{3}{|c|}{ ※:佮率 1\%以内で有意 }
\end{tabular}

移動フレームを適宜スライドさせて左右移動フレームに 取り付けたダイアルゲージの針の先端を壁面上の所定の 測定点に合わせることにより、相対的位置を測定するも のである。測定点の相対的位置は、 $\mathrm{x}$ 座標（水平かつ試 料壁面と平行な方向の座標），y 座標（鉛直かつ試料壁 面と平行な方向の座標）， $\mathrm{z}$ 座標(水平汃試料壁面と 直交する方向の座標）を用いて表示する。試料壁面と各 座標の方向との関係を図ー4 に示す。本装置では、x座 標は上下，左右各移動フレーム上に両者が水平になるよ う設けられた 2 つの測定基準点（図 - 3 参照）間の距離 を、y座標は固定フレームと上下移動フレーム上に両者 が鉊直になるよう設けられた 2 うの测定基準点（図一 3 参照) 間の距離を、それぞれのぎすで測定することによ り得ることができる。また $z$ 座標はダイアルゲージより

得ることができる。

本装置を用い、5.2で製作した試料壁面を構成する各夕

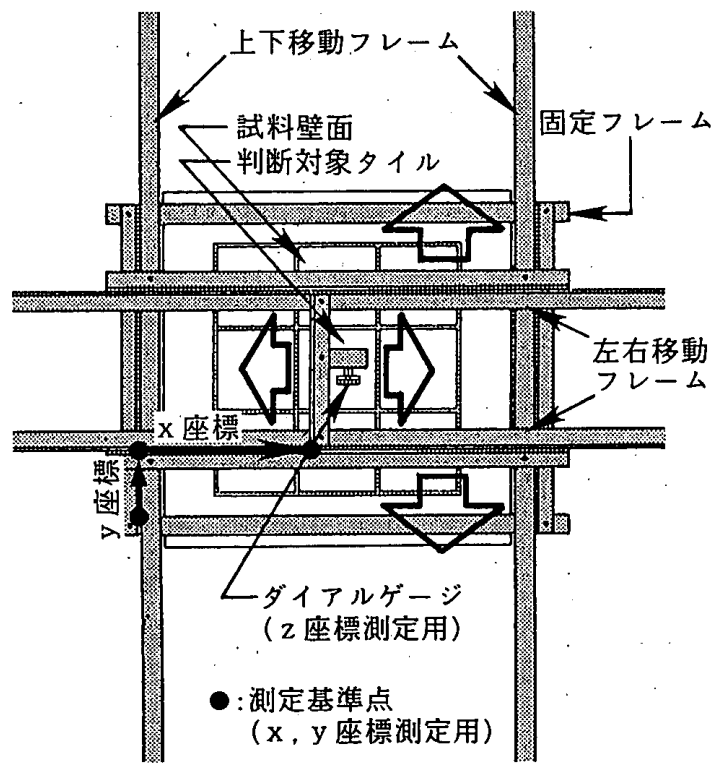

図-3 仕上げ精度測定装置の概要

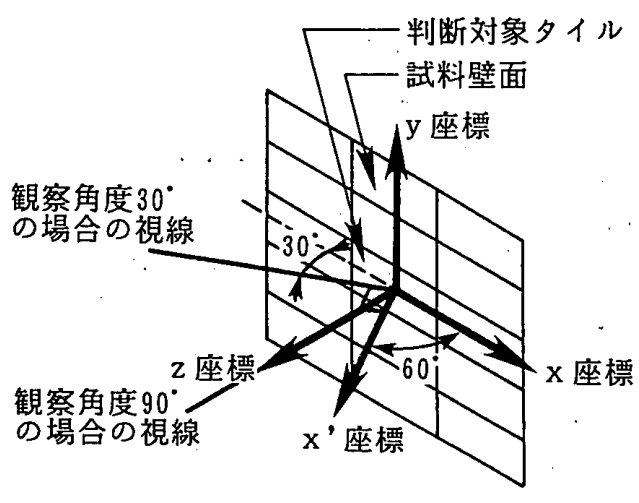

図-4 試料壁面, 視線と座標の方向の関係 
イルのうち、とりあえず前報で究明した判断対象範囲内 の 9 枚のタイルの四隅の相対的位置を測定した。なお凹 凸を有しない紙製試料の $\mathrm{z}$ 座標はいずれも同一である。 5.5 ずれ感覚を表示する物理量の設定

5.3.2で構成したずれ感覚尺度と5.4で測定した仕上げ 精度との関係から、ずれ感覚を表示する物理量について 以下のように検討した。

\section{[ I ] 観察角度 $90^{\circ}$ の場合}

観察角度 $90^{\circ}$ の場合、前報と同様、観察位置と判断対象 タイルとを結ぶ直線（以降“視線”と記す）と平行な $\mathrm{z}$ 方向の凹凸はずれ感覚にほとんど影響しないとみなし、 凹凸を有するタイル製試料の場合む含め、視線と直交す る $\mathrm{x}-\mathrm{y}$ 座標平面上から物理量を設定することとした。

下式に前報で設定したずれ感賞を表示する物理墨を示 す。

$\{\mathrm{dx}, \mathrm{dy}, \alpha \times \theta\} \max \left(\right.$ 単位 $\mathrm{mm}, \alpha=1 \mathrm{~mm} /{ }^{\circ}$ )

ここで $\mathrm{dx}, \mathrm{dy}$ は、判断対象タイル各隅での横，縦方 向の目地幅の変化量を表す。また $\theta$ は、判断対象夕イル 周囲のタイル各辺のうち判断対象タイルに隣接する辺之 判断対象タイル各辺との相対角度を表す。図ー 5 に例と して、判断対象タイル左下隅の $\mathrm{dx}, \mathrm{d} \mathrm{y}$ および上辺の $\theta$ の概要を示す。さらに上式の| 自axなる記号は、| \}内 に示した dx, dy， $\alpha \times \theta$ 各 4 個づつ計12個の中の最大值 を表すすのである。

上式は、判断対象範囲の仕上げ精度の測定結果から求 められる $\mathrm{dx}, \mathrm{dy}$ 計 8 個の中の最大値 $\{\mathrm{d} x, \mathrm{~d} y\} \max$ と、 $\theta 4$ 個の最大值 $\theta \max$ に係数 $\alpha$ を乗じた $\alpha \times \theta \max$ のうち

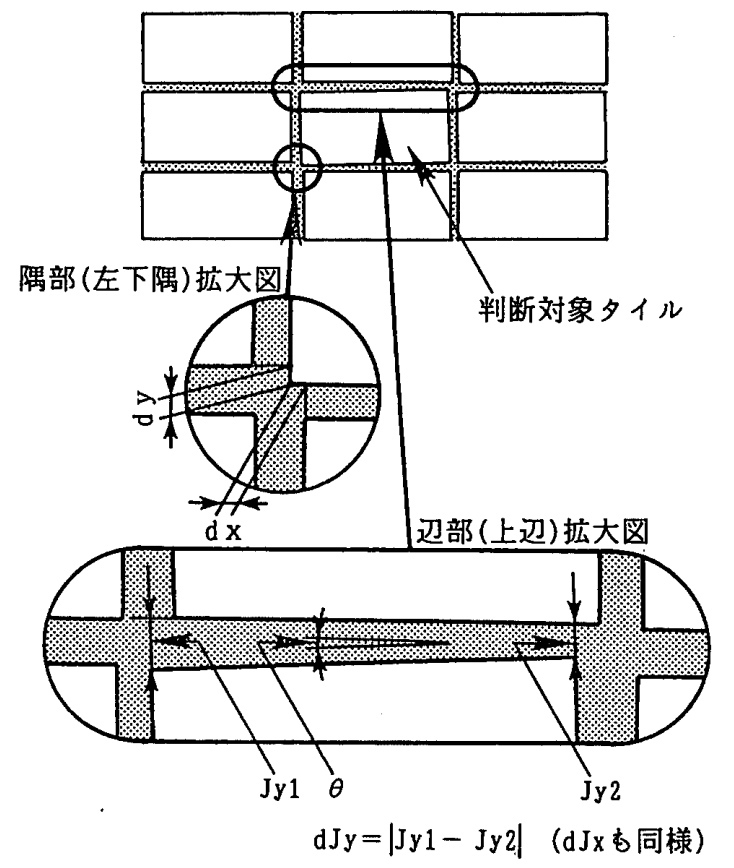

図一 $5 d x, d y, \theta, d J x, d J$ yの概要
どちらか大きい方の值を与えるすので、判断対象夕イル のずれは隅部での目地幅の変化量または边部の相対角度 により認知されること、判断対象タイルに対するずれ感 覚には隅部での目地幅の変化墨の最大值または辺部の相 対角度の最大値のうちいずれか一方が支配的に寄与して いることを示唆している。

本研究では、はじめに上式で示される物理量とずれ感 覚尺度との関係を検討した結果、 $\theta \max て ゙$ 物理量が決定す る試料壁面の一部が対応から外れることが判明した。す なわちタイルの大きさ, 形状などを要因として取り入れ た結果、辺部に起因するずれ感覚には $\theta$ だけでなく各辺 の長さす影響していることが考察された。そこで、隣接 する 2 辺のなす角度と辺の長さの 2 つの要因を考虑する こととし、種ヶ検討した結果、各辺の両端での目地幅の 変化量 $\mathrm{J} \mathrm{x}, \mathrm{d} J \mathrm{y}$ (図 -5 参照) が、辺部に起因するず れ感賞と密接な関係があることが想定された。

さらにタイルの大きさ，形状が同一で目地幅が異なる タイル壁面 $\mathrm{B}$ と C (表一 3 参照) の比較から、いくつか の試料壁面で目地幅の変化量が同程度ですずれ感覚が異 なることが考察された。すなわちずれ感覚には、目地幅 の変化の絶対墨だけでなく、周囲から想定される平均的 な目地幅に対する変化量の割合む大きく寄与しているこ とがうかがえた。ここで、周囲から想定される平均的な 目地幅は壁面本来の目地幅と大きな差はないと想定され ることから、簡便さを考慮し、目地幅の変化の絶対量と 壁面本来の繸，横目地幅 $\mathrm{J} \mathrm{x} ， \mathrm{~J} y$ に対する変化墨の割合 からなる物理量を設定することとした。種々検討の結果、 隅部での目地幅の変化に起因するず机感覚を表示する物 理量として

$\mathrm{C}_{\max }=\{\mathrm{dx} \times \mathrm{dx} / \mathrm{J} \mathrm{x}, \mathrm{dy} \times \mathrm{dy} / \mathrm{J} \mathrm{y}\} \max$

を、また辺部での目地幅の変化に起因するずれ感覚を表 示する物理量として

$S \max =\{d J x \times d J x / J x, d J y \times d J y / J y\} \max$ を設定した。

図ー6にC max と $\max$ の関係を示す。図中は官能検 查の検查員の意見および筆者らの判断などから、判断対 象タイルに対するずれ感覚に隅部での目地幅の変化が大 きく寄与していると思われた試料壁面であることを、○ は辺部での目地幅の変化が大きく寄与していると思われ た試料壁面であることを、

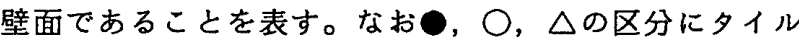
の大きさ，形状および目地幅による法則性は見られなか った。

図よりタイル壁面の種類にかかわらず、○と○との間 に図中一点鎖線で示した共通の境界線 $\mathrm{C} \max =\mathrm{S} \max$ が得 られることがわかる。すなわち $\mathrm{C}$ max $\geqq \mathrm{S} \max$ の試料壁面 では C max、C max<S maxの試料壁面では $S \max$ がずれ感 覚に支配的に寄与しており、ずれ感覚を表示する物理單 


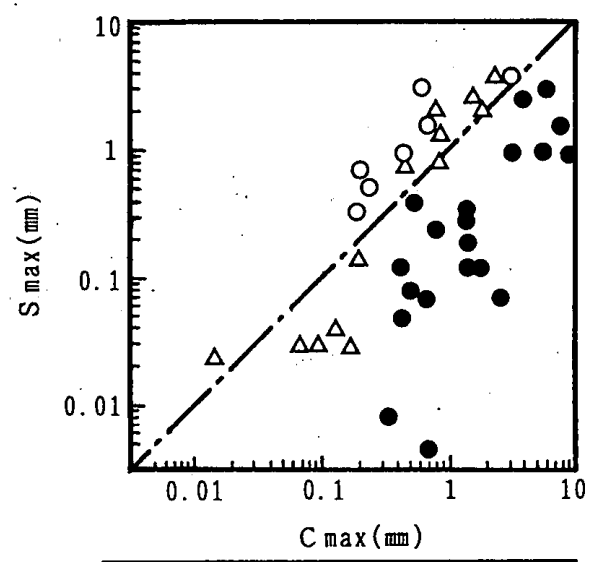

:隅部での目地幅の変化が 大きく奇与している試料壁面 :辺部での目地幅の変化が 大きく奇与している試料壁面 :どちらともえない試料壁面

図ー6C $\max$ と $\mathrm{S} \max$ の関係

として $\mathrm{C}$ max $\geqq S$ max の場合 $\mathrm{C}$ max、 $\mathrm{C}$ max $<\mathrm{S}$ maxの場合 $S \max$ が妥当である可能性が高いことがわかる。

以上より、ずれ感覚を表示する物理量として

$R \max =\{d x \times d x / J x, d y \times d y / J y$, $d J x \times d J x / J x, d J y \times d J y / J y$ ) max

を提案し、妥当性を検討することとした。

図-7の左側に観察角度 $90^{\circ}$ の場合のずれ感賞尺度と $R \max$ の関係を示す。図中の○は紙製試料、○はタイル製 試料を示し、(1)〜(7)の破線は表一 4 に示した判断範ちゅ うのずれ感覚尺度上の位置を表すすのである。両者はな めらかに対応しており、図中点線で示す対応の中心傾问 を表す曲線（以降“対応曲線”之記す）が容易に得られ ることより、R maxがずれ感覚を表示する物理量として妥 当であることがわかる。

[ II ]観察角度 $30^{\circ}$ の場合

観察角度 $30^{\circ}$ の場合む、前報と同様、視線と直交する座 標平面上から物理量を設定することとした。すなわち水 平かつ試料壁面とのなす角が $60^{\circ}\left(=90^{\circ}-30^{\circ}\right)$ の方向の $\mathrm{x}^{\prime}$ 座標（図－4 参照）を $\mathrm{x} ， \mathrm{z}$ 座標を合成することによ り求めたうえで、 $\mathrm{x}^{\prime}-\mathrm{y}$ 座標平面上から物理量を設定す ることとした。具体的には、各測定点の $\mathrm{x} ， \mathrm{z}$ 座標を

$$
x^{\circ}=x \sin 30^{\circ}+z \cos 30^{\circ}
$$

に代入することにより $x^{\prime}$ 座標を求めたうえで、[I ] で $\mathrm{x}-\mathrm{y}$ 座標平面上から $\mathrm{dx}, \mathrm{dy}, \mathrm{d} J \mathrm{x}, \mathrm{d} J \mathrm{y}$ を求めたのと 同様の手順にしたがって $x^{\prime}-\mathrm{y}$ 座標平面上から $\mathrm{dx} \mathrm{x}^{\prime}, \mathrm{dy}$, $\mathrm{d} J x^{\prime}, d J$ yを求め、さらに

$R \max =\int d x^{\prime} \times d x^{\prime} / J x^{\prime}, d y \times d y / J y$, $\left.d J x^{\prime} \times d J x^{\prime} / J x^{\prime}, d J y \times d J y / J y\right\} \max$ をずれ感覚を表示する物理量として提案し、妥当性を検 討することとした。したがって観察角度 $30^{\circ}$ の場合、タイ ル製試料の $\mathrm{z}$ 方向の凹凸は $\mathrm{x}$ 方向のずれと視線と平行な
観察角度 $30^{\circ}$

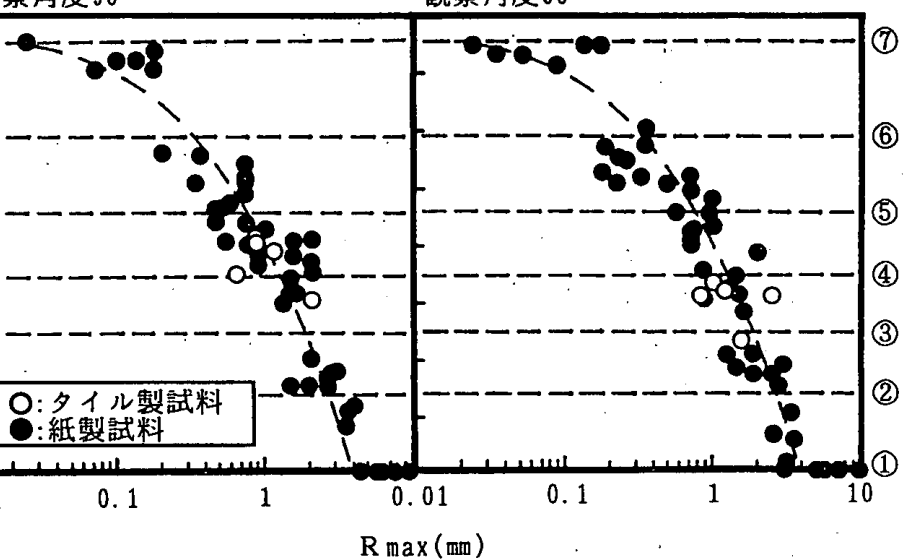

図ー7 ずれ感覚尺度と $R \max$ の関係

方向の凹凹とに分解され、このうち $\mathrm{x}$ 方向のずれが $\mathrm{R} \max$ に影響することとなる。

図-7の右側に観察角度 $30^{\circ}$ の場合のずれ感覚尺度と $\mathrm{R} \max$ の関係を示す。図中の記号および(1)〜(7)の破線の意 味は観察角度 $90^{\circ}$ の場合と同様である。［I］で述べたと同

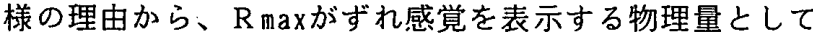
妥当であることがわかる。

[ I ]，［II]より、ずれ感覚を表示する物理量 $\mathrm{R} \max$ が設 定できたといえる。なお図ー7において、ずれ感覚尺度 と $\mathrm{R} \max$ の関係を表す対応曲線が観察角度 $90^{\circ}$ と $30^{\circ}$ でほぼ 等しいことから、ずれ感覚と $\mathrm{R}$ maxの関係は観察角度によ り大きく変化しないこと、本研究で対象としなかった角 度から観察する場合のずれ感覚も同様の方法で視線と直 交する座標平面上から求めら机る $\mathrm{R} \max$ で表示可能である ことがわかる。

以上であるが、9 枚以上のタイルを施工した試料壁面 です前報で究明した判断対象範囲内の 9 枚のタイルの仕 上げ精度の測定結果よりずれ感覚を表示する妥当な物理 量が設定できたことから、比較的小さいタイルからなる 壁面や辺長比の大きいタイルからなる壁面の短辺方向に 関しても、判断対象タイルのずれに関する判断が 9 枚の タイルの範囲から得られる視覚情報によりなされている ことが確認できたといえる。

さらに図ー7から、○で示したタイル製試料と○で示 した紙製試料が同一の曲線上に対応していることがわか る。このことと、前報および本報において凹凸を有する タイル製試料の場合であ視線と直交する座標平面上から 求められる物理量でずれ感覚を表示できたこと、すなわ ち紙製試料では具現できない凹凸による視線と平行な方 向の座標の細かい变化はずれ感覚に大きく影響しないと みなせることから、同等の視覚刺激が得られるタイル製 試料と紙製試料からは同等のずれ感覚が得られるとみな してあ大きな間違いとはならないことが確認できるとと 
あに、今後同種の刺激を対象とする研究においてタイル 製試料を紙製試料で置き換えることの妥当性が示唆され たものといえる。

\section{6. 結論}

1 種類のタイル壁面を対象とした前報の結果を参考に、 新たにタイルの大きさ，形状などを要因として取り入机 た本研究の結論をまとめると、以下の通りである。

・壁面を観察する際の距離とずれの目立ちやすさとの関 係を考察し、ずれが最す目立つ観察距離の範囲を求め た。

・壁面の仕上げ精度とずれ感賞との関係を考察し、判断 対象タイルに対するずれ感覚にはタイル隅部での目地 幅の変化量の最大值または辺部での目地幅の变化量の 最大值のうちいずれか一方が支配的に寄与しているこ と、ずれ感覚には目地幅の変化の絶対量だけでなく目 地幅に対する変化量の割合む大きく寄与していること を明らかにするととあに、ずれ感覚を表示する物理量 $\mathrm{Rmax}$ 設定した。

以上、前報で対象とした壁面とタイルの大きさ，形状 などが異なる壁面にす適用できるずれ感覚を表示する物 理量を設定した経過，結果を述べた。本研究結果は、種 々のタイル壁面に適用できるずれの目立ちやすさを表示 する物理量の設定、さらには視覚的観点からみたタイル
壁面の仕上げ精度の評価方法の提示のための基楚資料と して、有効と考える。

\section{謝辞}

本研究のテーマ, 研究方法の設定などにあたり種々御 指導いただいた小野英哲先生（東京工業大学教授・工博） に厚く御礼申し上げます。また本研究に対し有益な御助 言をいただくとともにタイル，目地材などを御提供いた だいた侏 I N A X の関係各位、ならびに官能検查などに 協力いただいた皆様に謝意を表します。

\section{参考文献}

1）横山 裕：1 種類のタイル壁面を対象としたずれ感覚を表 示する物理墨の設定 視党的観点からみたタイル壁面の仕 上げ精度の評価方法に関する研究（その1），日本建築学 会構造系論文報告集，第454号，pp. 1 8，1993年12月

2) 日本色彩学会: 新編色彩科学ハンドブック，1985年 9 月

3）松原道彦, 横山 裕: 視覚的観点からみたタイル壁面の仕 上げ精度の評価方法に関する研究 タイルの大きさ, 形状 などの要因を対象としたずれ感覚を表示する物理量の設定, 日本建筑学会大会学術講演概集 A, pp. 1335 1336, 1994年 9 月

4) J.P.Guilford著, 秋重義治監訳：精神测定法, 培風館, 1969年 